\title{
MODELING OF RESERVOIR INFLOW FOR HYDROPOWER DAMS USING ARTIFICIAL NEURAL NETWORK
}

\author{
A. W. Salami ${ }^{1}$, A. A. Mohammed ${ }^{2,}{ }^{*}$, J. A. Adeyemo ${ }^{3}$ and 0. K. Olanlokun ${ }^{4}$ \\ 1,4 DEPARTMENT OF CIVIL ENGINEERING, UNIVERSITY OF ILORIN, ILORIN, NIGERIA \\ 2 National CENTRE For HydropoWER RESEARCh AND DEVELOPMENT, UNIVERSITY OF ILORIN, ILORIN, NIGERIA

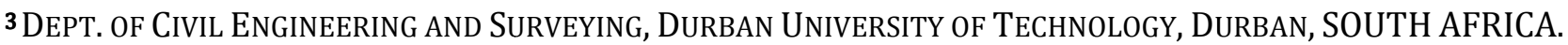 \\ E-mail Addresses:1awsalami2009@gmail.com,2rasaq.muhammed@yahoo.com,3josiaha@dut.ac.za, \\ 4yemilokun@yahoo.co.uk
}

\begin{abstract}
The stream flow at the three hydropower reservoirs in Nigeria were modeled using hydro-meteorological parameters and Artificial Neural Network (ANN). The model revealed positive relationship between the observed and the modeled reservoir inflow with values of correlation coefficient of $0.57,0.84$ and 0.92 for Kainji, Jebba and Shiroro hydropower reservoir respectively. The established model was used to predict 20 years stream-flow for each of the hydropower reservoirs which were found to have similar statistics with the observed values. The predicted reservoir inflow were subjected to trend analysis which revealed an upward trend with percentage increase of $4.58 \%, 6.34 \%$ and 5.42\% for Kainji, Jebba and Shiroro hydropower reservoirs respectively. The upward trend is an indication of increase in water availability for hydropower generation at the three stations given other constraints are brought under control.
\end{abstract}

Keywords: Reservoir inflow, Hydropower dams, Hydro-meteorological variables, Artificial Neural Network and Hydrologic process

\section{INTRODUCTION}

Water Resources data need correct measurement, analysis and reliable estimates for future planning and current operations for its purposes such as: drinking water, irrigation and energy production [1]. Forecasting streamflow is an important task since it can help in short term operation of water resources systems as well as providing early warning of river flooding. Accurate and reliable forecasts of catchment runoff are crucial for successful management of water resources are particularly important in the occurrence of hydrological extremes such as floods and droughts. Accurate and timely inflow forecasting is crucial for effective hydropower reservoir operation and flooding prevention because it can provide an extension of lead-time of the inflow into the reservoir forecasting [2].

The need for this study cannot be over-emphasised, adequate inflow data modeling and forecasting is very essential for proper operation, optimization and maintenance of hydropower system. The study was carried out to sensitize the stakeholders at the three hydropower stations in Nigeria on the likely volume of future inflow into their reservoirs for effective planning. The study aims at modeling the reservoir inflow to hydropower dams in Nigeria for effective planning and management. The objectives of the study are: to collect hydro-meteorological parameters from the hydropower stations, to model reservoir inflows, calibrate and validate the model and forecast the future inflow into the reservoirs.

The general difficulty associated with streamflow forecasting is the non-linear and non-stationary characteristics which are often encountered inmost streamflow time series data. Artificial neural networks (ANN) models are considered as a category of the data-driven techniques, have been widely used in streamflow forecasting. Several distinguishing features of ANN models make them valuable and attractive for forecasting tasks. First, there are few a priori assumptions about the models as opposed to model-driven techniques. They learn from examples 
and capture the functional relationships among the data even if the underlying relationships are too complex to specify [3].

Artificial neural network (ANN) has been widely applied in modeling of many nonlinear hydrologic processes such as numerical weather and global climate model [4], rainfall-runoff model [5] and [6], stream flow model [7], [8] and [9], precipitation prediction [10] and [11], rainfall modeling [12], [13] and [14] and simulation of daily temperature [15]. ANN have been trained to perform complex functions in various fields, including pattern recognition, identification, traffic prediction, classification, speech, vision and control systems [16]. According to Khaing andThinn among forty eight (48) studies conducted using ANN between 1988 and 1994, it was found that neural network models produced superior predictions [11]. Adya and Collopy reviewed effectiveness of ANN in forecasting and predicting flow. They stated that effectively implemented and validated, ANN outperformed all comparative methods such as linear regression, stepwise polynomial regression, multiple regression, discriminant analysis, logic models and rule-based system [17].

Dibike and Solomatine studied the river flow forecasting using ANN model in the Apure river basin in Venezuela. Two types of ANN architectures namely multilayer perceptron network (MLP) and radial basis function networks (RBF) were implemented. The data used for the analysis are weekly precipitation, evapotranspiration and runoff for the period of five years. The result revealed that the model was found to be slightly better for river flow forecasting problem [18]. Solaimani assessed the rainfall-runoff prediction based on ANN in Jarahi Watershed in Iran. The study was aimed at modeling the rainfall-runoff relationship in the catchment area. The results indicated that the ANN model is appropriate and efficient to predict the river runoff [19]. Kothyari estimated mean annual flood from ungauged catchments with mean annual flood and average rainfall value for two year return period using ANN model. Two ANN model architectures: multilayer perceptron architecture, in which back propagation algorithms (BPANN) were used and the cascade correlation architecture (CCANN) were used to evaluate performance of ANNs in estimating reference evapotranspiration with minimal meteorological data [20]. Diamantopoulou et al stated that ANNs have shown great ability in modeling and forecasting non-linear and nonstationary time series [21]. ANN model in most cases especially in drought prediction have showed very good performance [22].

Jeong and Kim assessed rainfall-runoff for ensemble streamflow prediction using two types of ANN, namely the single neural network (SNN) and the ensemble neural network (ENN), to provide better rainfallrunoff simulation capability. The overall results showed that the ENN performed better than the SNN in modeling rainfall-runoff [23]. Pulido-Calvo et al carried out study on water resources management in the Guadalquivir River Basin, Southern Spain using ANN model to simulate the inflow and outflow in a water resources system under shortage of water. Hydro-meteorological data from various gauging stations were used in this study. Weekly data were used for the analysis for the period of eight years. Data of six years were used for model calibration and the remaining two years data were used for the validation. The results demonstrated that the neural approach approximated the behaviour of various components of the water resources system in terms of various hydrologic cycle processes and management rules [24]. Demirel and Booij studied the identification of an appropriate low flow forecast model for the Meuse River in Netherlands based on the comparison of output uncertainties of different models. Three models were developed for the Meuse River such as multivariate, linear regression and ANN models. The uncertainty in the three models was assumed to be represented by the difference between observed and simulated discharge. The data used for the study were discharge, precipitation and evapotranspiration for thirty years (1968-1998). Twenty years data was used for the model calibration while ten years data was used for validation of the result. The results obtained using ANN model revealed that the low flow forecast model performed slightly better than the other statistical models in forecasting low flows for a lead time of seven days [25]. This study provided basis that was adopted in this study.

Valent et al stated that the assessment of the performance of various calibration techniques have to deal with a certain amount of uncertainty in the calibration data. In their study, assessment of the uncertainties of a conceptual hydrologic model using artificially generated flows from Hydrologiska Byrans Vattenbalansavdelning (HBV) model. Calibration procedures was tested in hypothetically ideal conditions under the assumption of no errors in the measured data. This was achieved by creating an artificial time series of the flows created by the HBV 
model using parameters obtained from calibrating the measured flows. The artificial flows were then used to replace the original flows in the calibration data, which was then used for testing how calibration procedures can reproduce known model parameters. The results showed that in performing one hundred independent calibration runs of the HBV model, it was observed that the obtained parameters were almost identical to those used to create the artificial flow data without a certain degree of uncertainty [26].

The aim of this paper is to present the modelling of the reservoir inflow at the Kainji, Jebba and Shiroro hydropower reservoirs based on hydrometeorological parameters using Artificial Neural Networks for forecasting purposes. The Kainji and Jebba hydropower dams were constructed across the River Niger in 1968 and 1984 respectively, while Shiroro hydropower dam was constructed across River Kaduna in 1990. The installed capacity is 760 MW, 540 MW and 600 MW for Kainji, Jebba and Shiroro respectively. River Niger is divided into upper Niger, middle Niger and lower Niger. The power stations are located in the middle Niger in Nigeria.

\section{MATERIALS AND METHODS}

\subsection{Data collection}

The data required for this study are hydrometeorological data which were obtained for a period of 20-42 years from the hydrologic section of the three hydropower dams in Nigeria. The data include precipitation $(\mathrm{mm})$, evaporation, temperature $\left({ }^{\circ} \mathrm{C}\right)$ and reservoir inflow $\left(\mathrm{m}^{3} / \mathrm{s}\right)$ for the three hydropower reservoirs in Nigeria. The missing hydrometeorological data were supplied using statistical methods [27].Table 1 shows three hydropower stations and year of available hydro-meteorological data.

\subsection{Data analysis}

Artificial Neural Network (ANN) was used to model reservoir inflow as a function of meteorological parameters such as precipitation, temperature and evaporation. That is, the input variables are: precipitation, temperature and evaporation while, the output variable is reservoir inflow at the three hydropower reservoirs. The ANN model in the 'Alyuda forecaster XL' softwares was used for the analysis. The model was trained (calibrated), validated and tested with the available hydro-meteorological parameters in the selected stations using error back propagation algorithm in order to speed up its convergence to a minimum error [28].

\section{RESULTS AND DISCUSSION}

The ANN model for Kainji was trained with 30 years hydro-meteorological data (1970-1999), Jebba was trained with 20 years hydro-meteorological data (1984-2007) and Shiroro was trained with 14 years hydro-meteorological data (1990-2003). In validating the ANN model for Kainji, seven years hydrometeorological data (2000-2006) was used, while 4 years hydro-meteorological data (2004-2007) was used to validate those of Jebba and Shiroro. However, for the model testing, five years hydro-meteorological data (2007-2011) was used for Kainji, while Jebba and Shiroro were tested with 4 years hydrometeorological data (2008-2011).

The summaries of ANN model analyses for the hydrometeorological parameters at the selected locations are presented in the Tables 2 to 4 , while the comparison between the actual and forecasted reservoir inflow is depicted in Figure 1 to 3 for Kainji, Jebba and Shiroro respectively. Also Figures 4 to 6 depict the linearity between the actual and forecasted reservoir inflow for Kainji, Jebba and Shiroro respectively.

Table 1.Hydropower reservoirs and geographical location of study areas

\begin{tabular}{ccccc}
\hline \multirow{2}{*}{ River } & \multirow{2}{*}{ Location } & Year of record & \multicolumn{2}{c}{ Coordinate } \\
\cline { 4 - 5 } & Kainji & $1970-2011$ & $9^{\circ} 50^{\prime}$ & $4^{\circ} 40^{\prime}$ \\
Niger & Jebba & $1984-2011$ & $9^{\circ} 08^{\prime}$ & $4^{\circ} 49^{\prime}$ \\
Niger & Shiroro & $1990-2011$ & $9^{\circ} 58^{\prime} 25^{\prime \prime}$ & $6^{\circ} 50^{\prime} 6^{\prime \prime}$ \\
Kaduna & &
\end{tabular}

Table 2: ANN model summary for Kainji hydropower dam

\begin{tabular}{lllllll}
\hline $\begin{array}{l}\text { Sample } \\
\text { partition }\end{array}$ & $\begin{array}{l}\text { Data } \\
\text { (month) }\end{array}$ & $\begin{array}{l}\text { Percentage } \\
(\%)\end{array}$ & SSE & RE & $\mathrm{R}^{2}$ & $\mathrm{r}$ \\
\hline Training & 360 & 71.4 & 4.014 & 0.642 & 0.19 & 0.57 \\
Validation & 84 & 16.7 & 1.967 & 0.839 & & \\
Testing & 60 & 11.9 & & 0.842 & & \\
Total & 504 & 100 & & & & \\
\hline
\end{tabular}


Table 3: ANN model summary for Jebba hydropower dam

\begin{tabular}{|c|c|c|c|c|c|c|}
\hline $\begin{array}{l}\text { Sample } \\
\text { partition }\end{array}$ & $\begin{array}{l}\text { Data } \\
\text { (month) }\end{array}$ & $\begin{array}{l}\text { Percentage } \\
(\%)\end{array}$ & SSE & $\mathrm{RE}$ & $\mathrm{R}^{2}$ & $r$ \\
\hline Training & 240 & 71.4 & 94.93 & 0.999 & 0.67 & 0.84 \\
\hline Validation & 48 & 14.3 & 32.79 & 0.973 & & \\
\hline Testing & 48 & 14.3 & & 0.997 & & \\
\hline Total & 336 & 100 & & & & \\
\hline
\end{tabular}

Table 4: ANN model summary for Shiroro hydropower dam

\begin{tabular}{lllllll}
\hline $\begin{array}{l}\text { Sample } \\
\text { partition }\end{array}$ & $\begin{array}{l}\text { Data } \\
\text { (month) }\end{array}$ & $\begin{array}{l}\text { Percentage } \\
(\%)\end{array}$ & SSE & RE & $\mathrm{R}^{2}$ & $\mathrm{r}$ \\
\hline Training & 168 & 63.4 & 32.53 & 0.392 & 0.85 & 0.92 \\
Validation & 48 & 18.3 & 8.60 & 0.417 & & \\
Testing & 48 & 18.3 & & 0.294 & \\
Total & 264 & 100 & & & \\
Key: SSE = Sum of square error, & $\mathrm{RE}=$ Relative error & $\mathrm{R}^{2}=$ Coefficient of determination \\
\multicolumn{7}{r}{ r= Correlation coefficient }
\end{tabular}

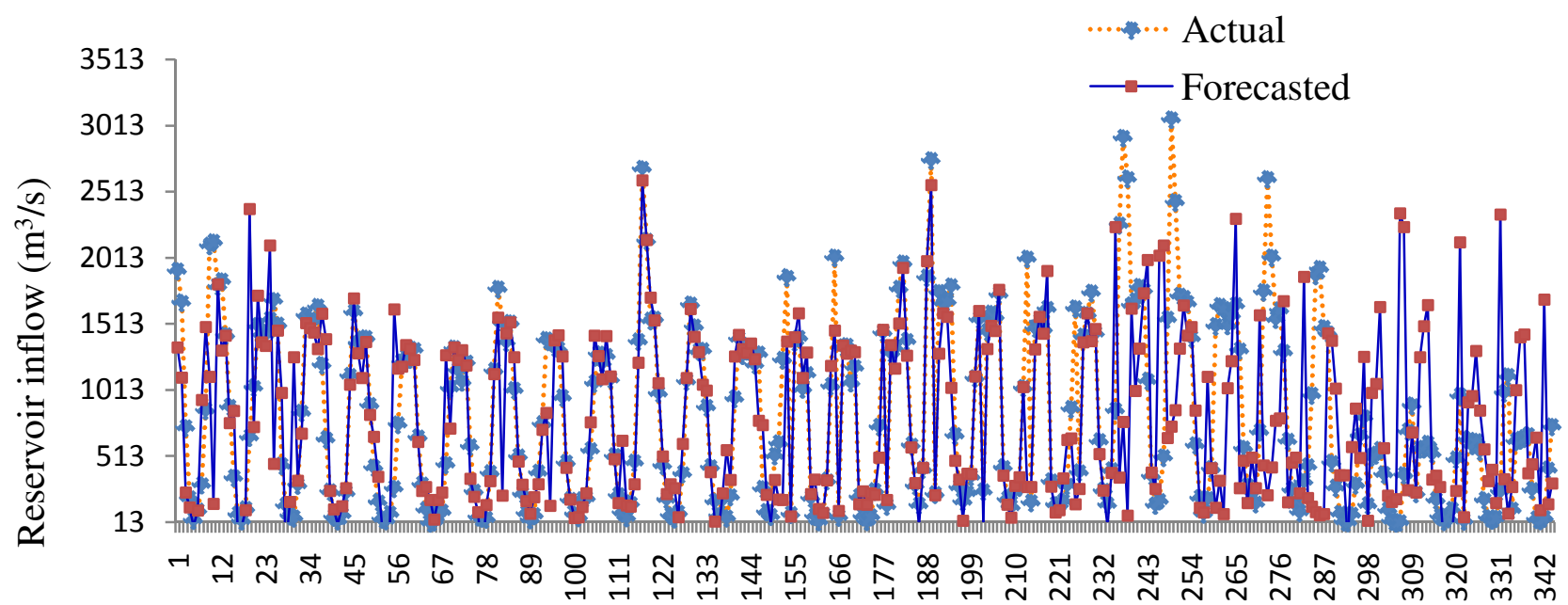

Time (month)

Figure 1: Actual and forecasted reservoir inflow for Kainji

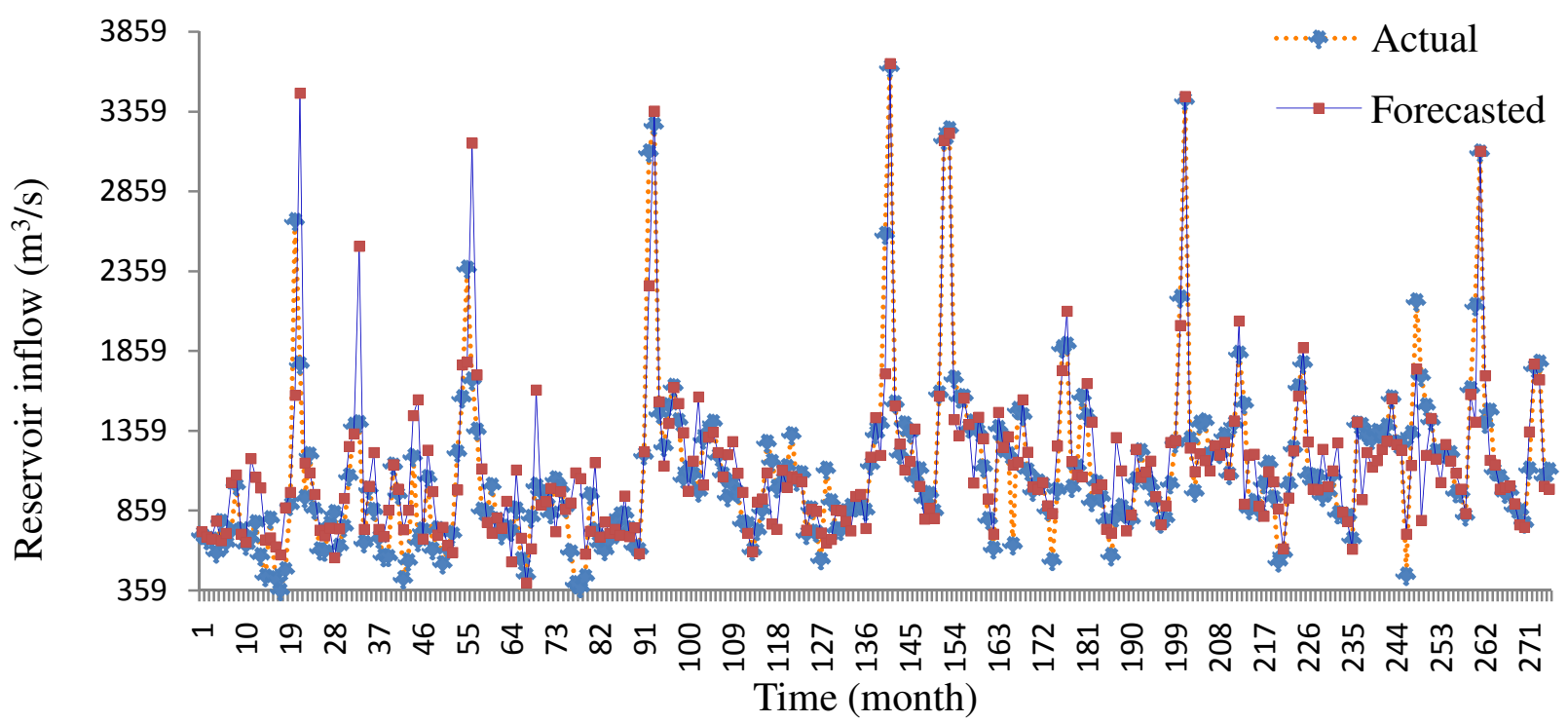

Figure 2: Actual and forecasted reservoir inflow for Jebba 


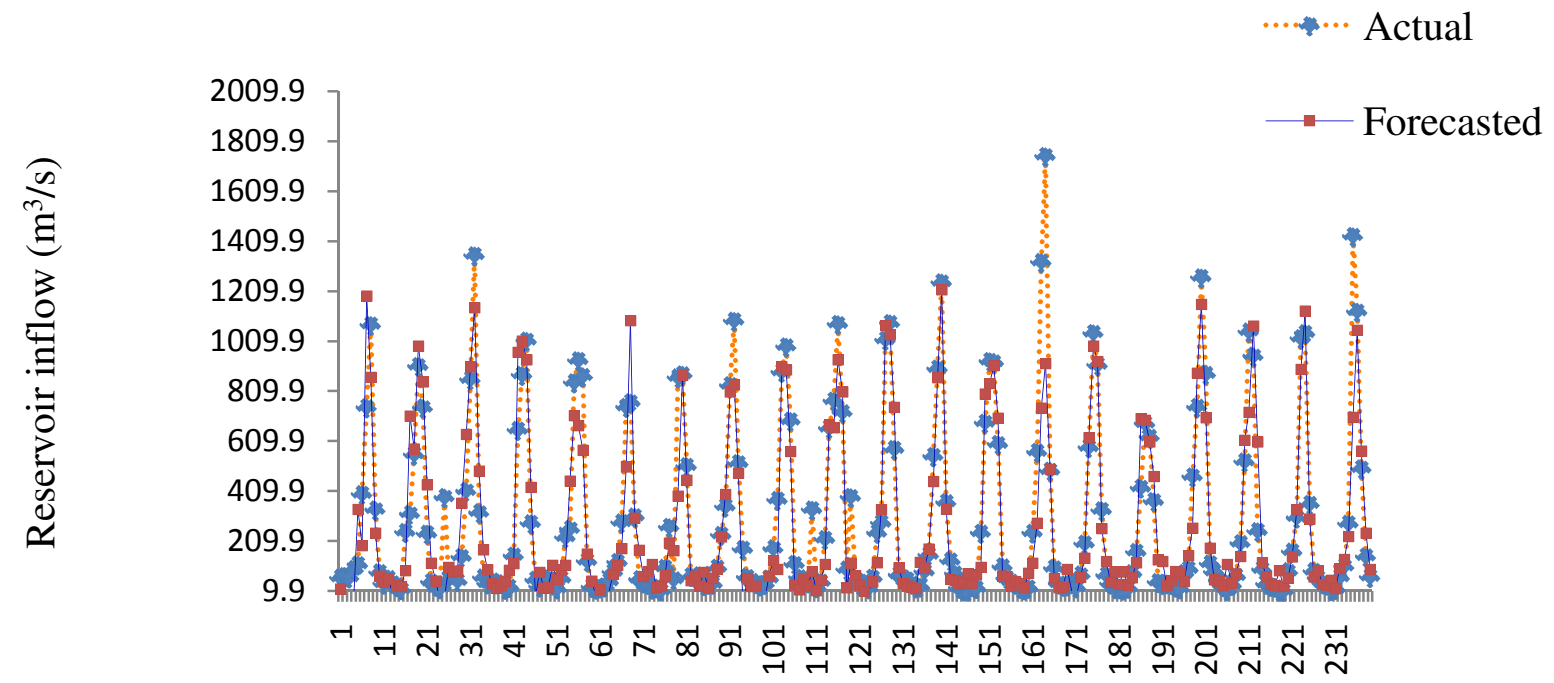

Time (month)

Figure 3: Actual and forecasted reservoir inflow for Shiroro

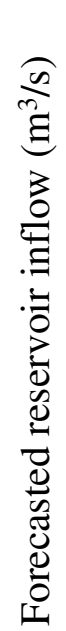

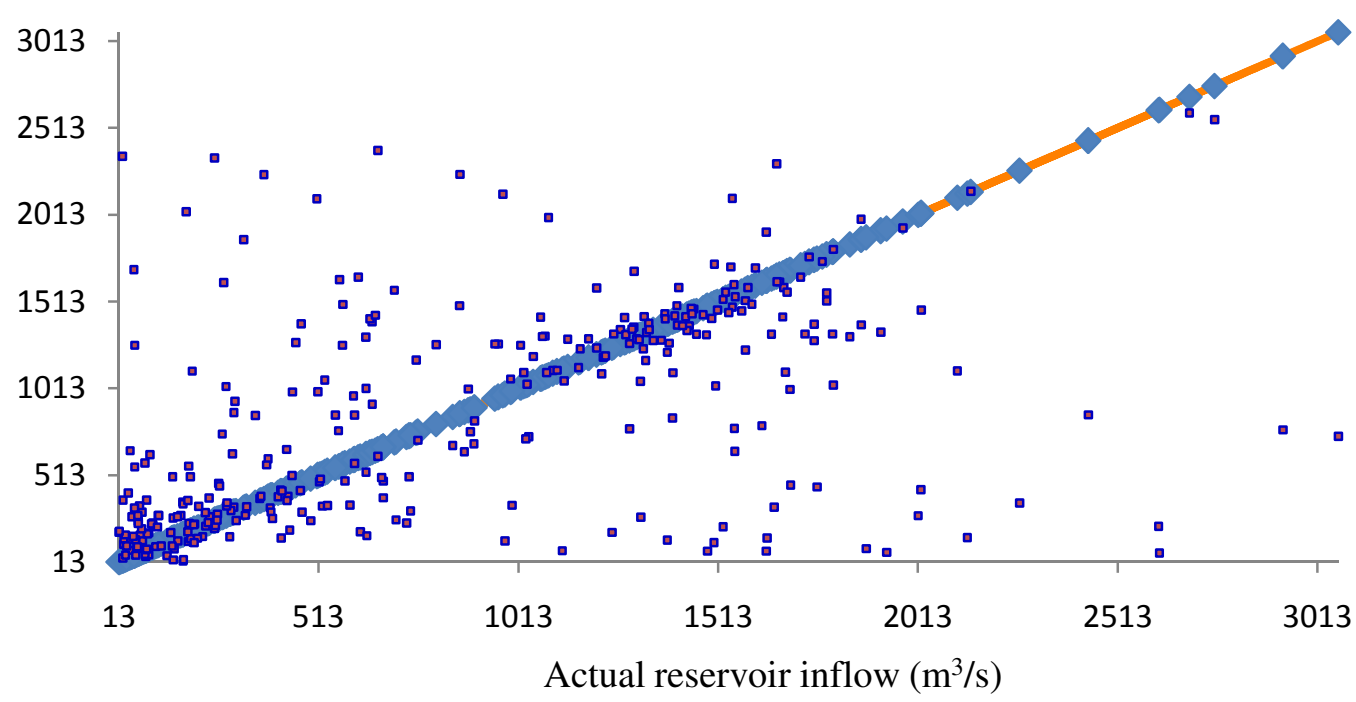

Figure 4: Scatter plot of forecasted and actual reservoir inflow for Kainji

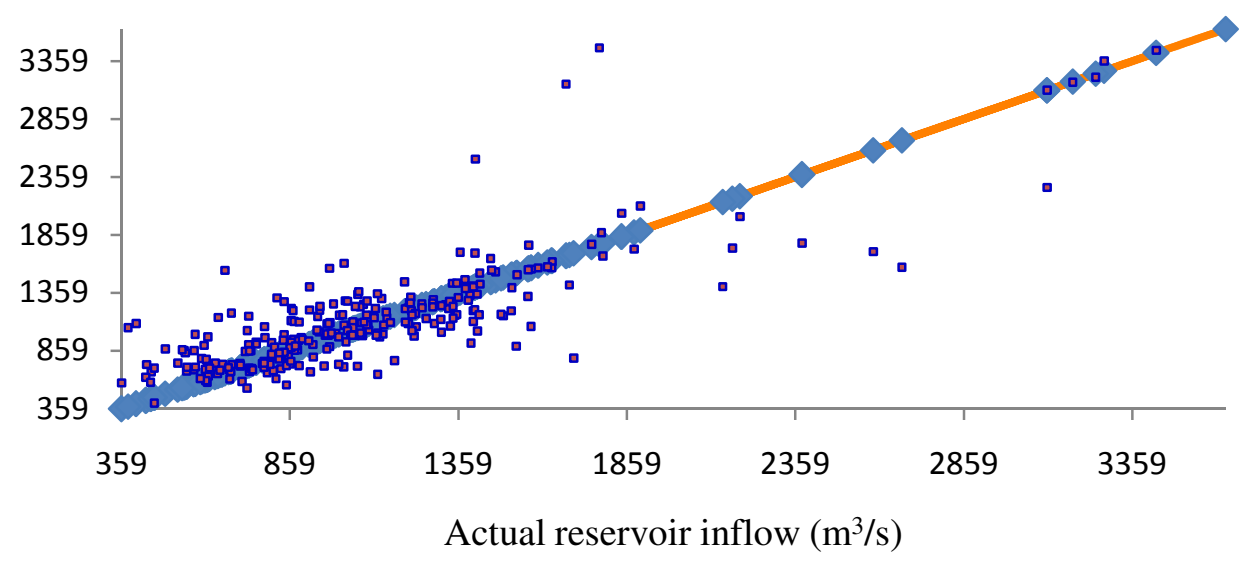

Figure 5: Scatter plot of forecasted and actual reservoir inflow for Jebba 


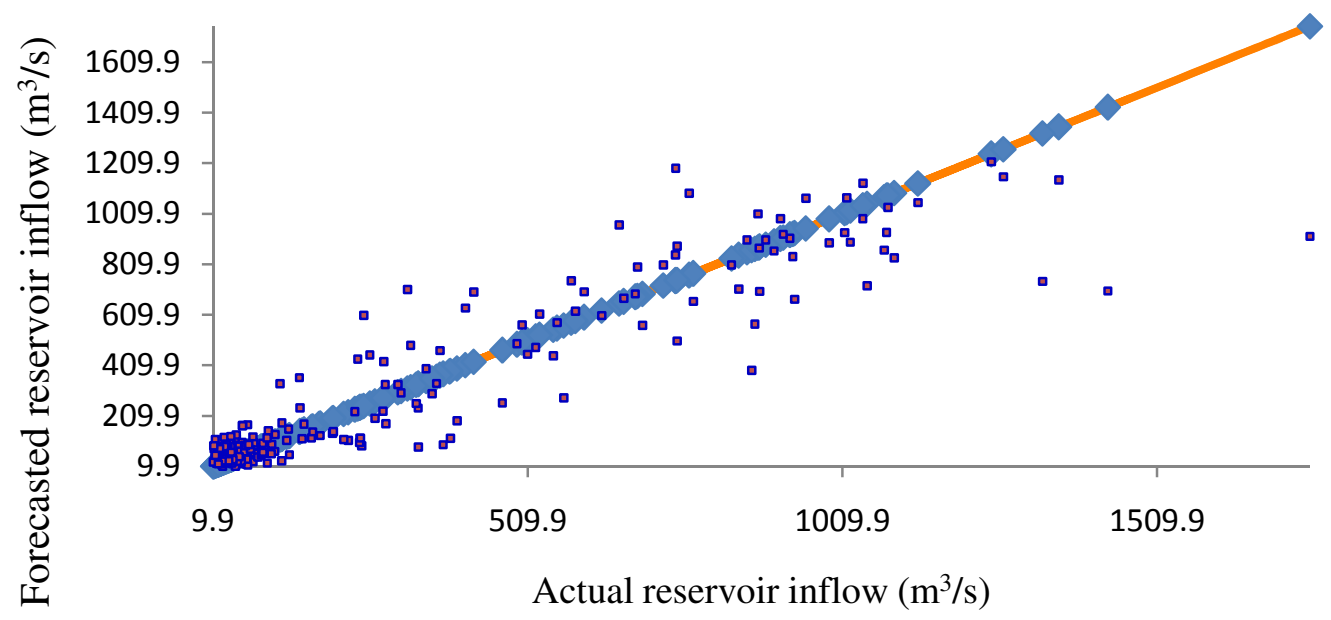

Figure 6: Scatter plot of forecasted and actual reservoir inflow for Shiroro

Table 5: Statistical summary of predicted reservoir inflow for Kainji reservoir (2011-2030)

\begin{tabular}{ccccccccccccc}
\hline Parameters & Jan & Feb & Mar & Apr & May & Jun & Jul & Aug & Sep & Oct & Nov & Dec \\
\hline Mean & 300.29 & 396.75 & 463.33 & 516.41 & 568.76 & 599.03 & 613.46 & 664.23 & 738.94 & 856.35 & 596.92 & 558.97 \\
Std Dev & 121.96 & 77.70 & 63.26 & 49.04 & 78.91 & 62.73 & 56.23 & 67.66 & 91.12 & 134.48 & 51.56 & 51.40 \\
CV & 0.41 & 0.20 & 0.14 & 0.09 & 0.14 & 0.10 & 0.09 & 0.10 & 0.12 & 0.16 & 0.09 & 0.09 \\
Skew & -0.12 & -0.44 & -0.24 & 0.81 & 1.58 & 0.42 & -0.90 & -0.54 & 0.60 & 0.96 & -0.62 & -1.01 \\
Max & 491.86 & 512.20 & 564.97 & 640.99 & 812.98 & 757.04 & 706.00 & 802.92 & 987.87 & 1185.1 & 668.65 & 642.54 \\
Min & 68.92 & 214.86 & 337.25 & 448.66 & 462.91 & 465.89 & 485.09 & 508.08 & 542.66 & 687.21 & 485.66 & 415.38 \\
\hline
\end{tabular}

Table 6: Statistical summary of predicted reservoir inflow for Jebba reservoir (2011-2030)

\begin{tabular}{ccccccccccccc}
\hline Parameters & Jan & Feb & Mar & Apr & May & Jun & Jul & Aug & Sep & Oct & Nov & Dec \\
\hline Mean & 1168.0 & 1156.8 & 1182.9 & 1162.1 & 1219.5 & 1140.1 & 1189.0 & 1125.7 & 1137.8 & 1172.6 & 1163.7 & 1149.6 \\
Std Dev & 161.17 & 129.06 & 179.74 & 104.39 & 159.59 & 149.16 & 110.04 & 83.85 & 133.39 & 200.32 & 171.44 & 129.80 \\
CV & 0.14 & 0.11 & 0.15 & 0.09 & 0.13 & 0.13 & 0.09 & 0.07 & 0.12 & 0.17 & 0.15 & 0.11 \\
Skew & 0.57 & 1.83 & 0.49 & 0.48 & 0.15 & 0.53 & 0.27 & 0.19 & -0.50 & -0.01 & 0.13 & 0.33 \\
Max & 1622.4 & 1568.4 & 1548.6 & 1373.4 & 1572.9 & 1473.6 & 1454.2 & 1286.3 & 1354.2 & 1619.2 & 1576.3 & 1407.6 \\
Min & 818.11 & 959.73 & 932.25 & 993.54 & 864.84 & 837.65 & 994.59 & 971.17 & 819.63 & 765.12 & 818.34 & 973.20 \\
\hline
\end{tabular}

Table 7: Statistical summary of predicted reservoir inflow for Shiroro reservoir (2011-2030)

\begin{tabular}{ccccccccccccc}
\hline Parameters & Jan & Feb & Mar & Apr & May & Jun & Jul & Aug & Sep & Oct & Nov & Dec \\
\hline Mean & 26.36 & 36.65 & 44.10 & 47.95 & 52.15 & 57.98 & 67.86 & 76.45 & 74.55 & 96.66 & 63.29 & 44.86 \\
Std Dev & 7.68 & 14.48 & 16.66 & 16.00 & 19.19 & 28.44 & 35.09 & 55.79 & 20.76 & 45.56 & 24.40 & 27.35 \\
CV & 0.29 & 0.40 & 0.38 & 0.33 & 0.37 & 0.49 & 0.52 & 0.73 & 0.28 & 0.47 & 0.39 & 0.61 \\
Skew & 0.52 & 2.03 & 1.52 & 1.73 & 2.38 & 3.38 & 3.54 & 4.18 & 0.68 & 1.97 & 1.52 & 1.98 \\
Max & 43.26 & 81.58 & 87.98 & 94.82 & 116.17 & 167.01 & 205.24 & 308.45 & 124.37 & 235.39 & 134.35 & 132.16 \\
Min & 12.96 & 21.70 & 23.37 & 32.35 & 34.09 & 38.57 & 41.01 & 51.80 & 30.35 & 40.75 & 32.23 & 10.68 \\
\hline
\end{tabular}

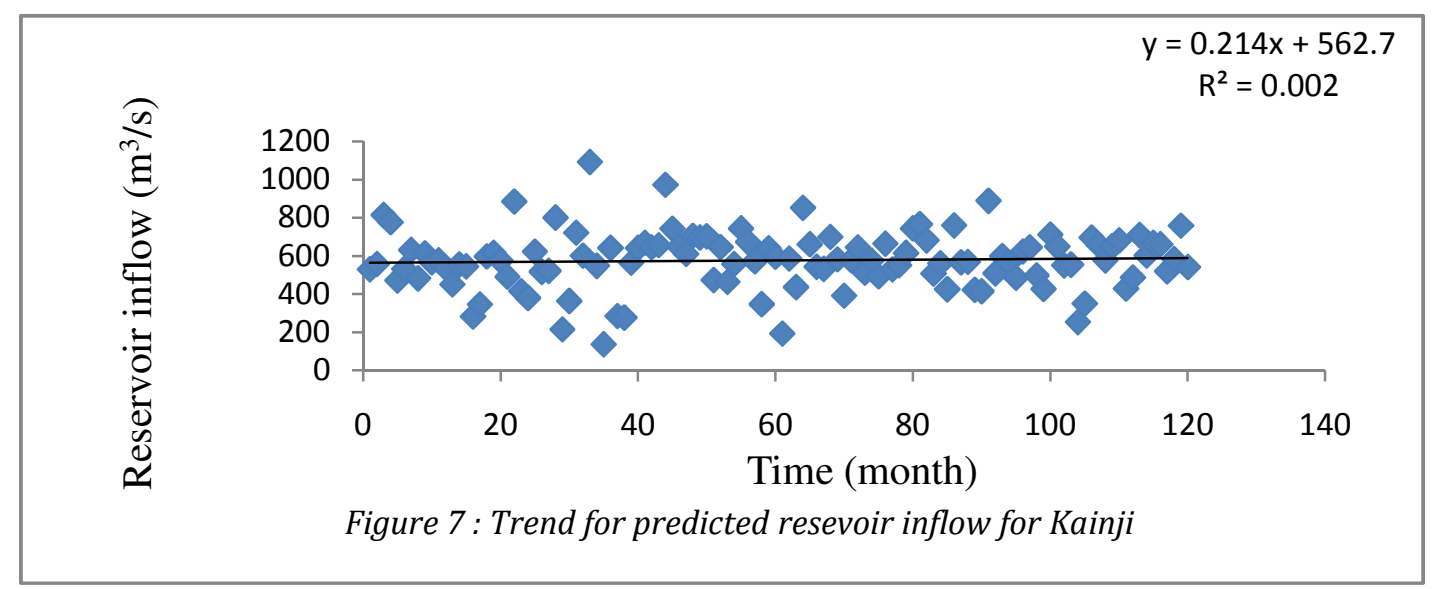




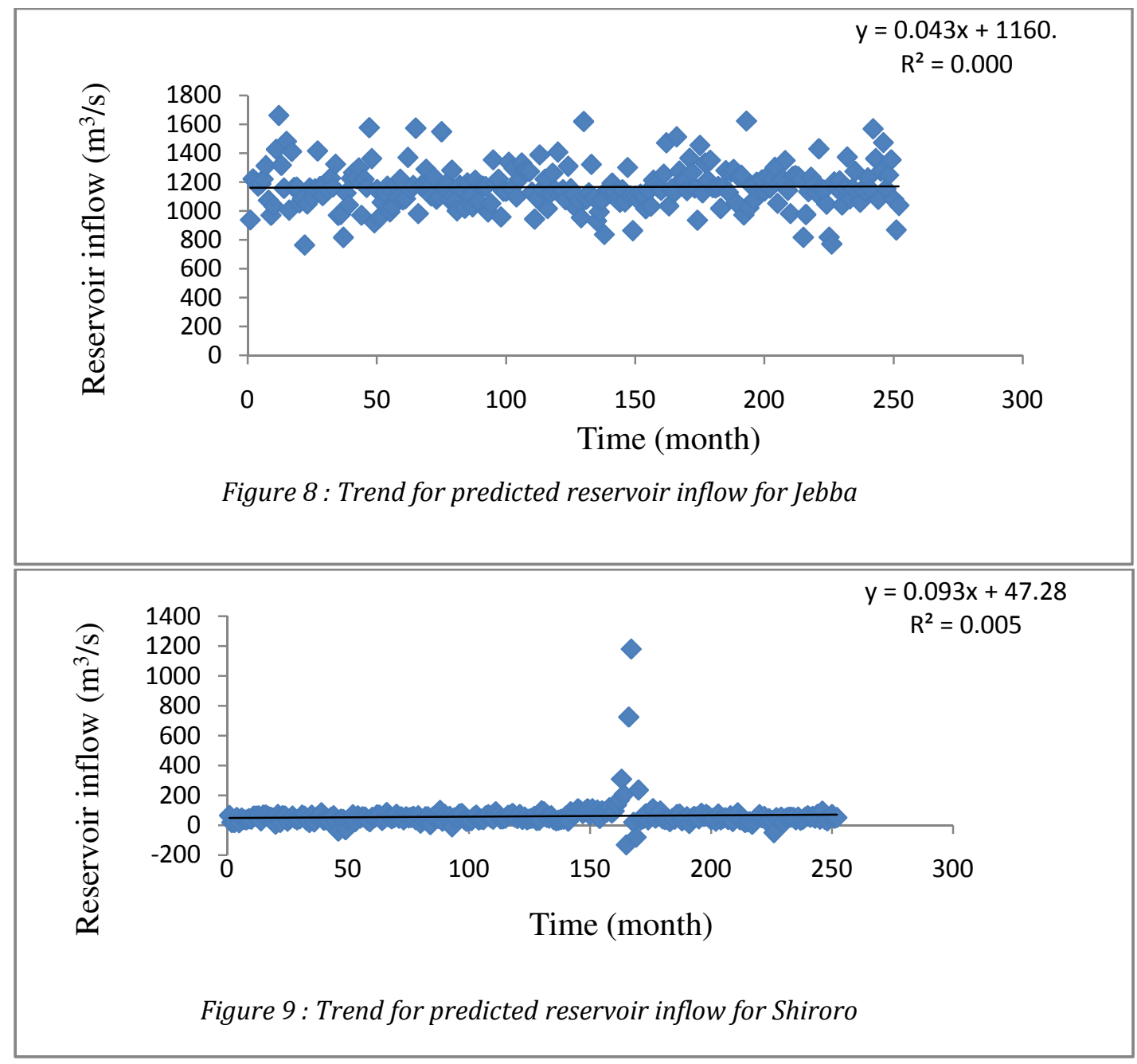

\subsection{Prediction of Reservoir Inflows}

The trained and tested ANN model was used to predict the monthly runoff for Kainji, Jebba and Shiroro from year 2011-2030. The statistical summary of the predicted reservoir inflow are presented in Table 5 to 7 for Kainji, Jebba and Shiroro hydropower dams respectively. The mean values of the predicted monthly runoff data were subjected to trend analysis to show the trend pattern in the locations. Figures 7 to 9 depict the trend pattern for the predicted reservoir inflow at Kainji, Jebba and Shiroro stations respectively. In order to determine the percentage variation of the predicted reservoir inflow, the mean annual predicted inflow was subjected to percentage variation and the estimated variations are $+4.58 \%$, $+6.34 \%$ and $+5.42 \%$ for Kainji, Jebba and Shiroro respectively.

The hydropower reservoirs and their geographical location were presented in Table 1 . The result of the statistical summary for ANN model was presented in Table 2 to 4 , while the statistical summary of the forecasted reservoir inflow was presented in Tables 5 to 7 for Kainji, Jebba and Shiroro hydropower reservoir respectively. Moreover, the variation of the actual and forecasted reservoir inflow with time was presented in Figures 1 to 3 , while the linear relationship between the actual and the forecasted reservoir inflow was depicted in Figures 4 to 6 for Kainji, Jebba and Shiroro hydropower reservoir respectively. The trend of the forecasted reservoir inflow was also depicted in Figure 7 to 9 in order to detect the nature of the trend.

The summaries of the ANN model results show the percentage of data used for model calibration, validation and testing, sum of square error (SSE) and relative error (RE). The results for Kainji show that about $71 \%, 17 \%$ and $12 \%$ of the data were used for ANN model training, validation and testing respectively. The SSE for training data at Kainji station is 4.014 and its RE is 0.642 while its validation has SSE of 1.967, RE of 0.839 and the testing has RE of 0.842 . $\mathrm{R}^{2}$ and $\mathrm{r}$ were 0.19 and 0.57 respectively which revealed a positive relationship between the actual and the forecasted reservoir inflow for Kainji. The results for Jebba show that about 72\%, 14\% and $14 \%$ respectively were used for calibration, validation and 
testing. The SSE for the training data at Jebba station is 94.931 and its RE is 0.999 while its validation has SSE of 32.793 and RE of 0.973 and the testing has RE of $0.997, \mathrm{R}^{2}$ and $\mathrm{r}$ were 0.67 and 0.84 respectively which revealed a positive relationship between the actual and the forecasted reservoir inflow for Jebba. The results for Shiroro show that about 64\%, 18\% and 18 $\%$ respectively were used for calibration, validation and testing, while the SSE for the training data at Shiroro station is 32.524 and its RE is 0.392 while its validation has SSE of 8.602 and RE of 0.417 and the testing has RE of $0.294 . \mathrm{R}^{2}$ and $\mathrm{r}$ were 0.85 and 0.92 respectively which depict a positive relationship between the actual and the forecasted reservoir inflow for Shiroro. The correlations ( $r$ ) for the three stations are all above 0.5 ; this implies that the results obtained for the stations are adequate for effective forecasting of reservoir inflow. The forecasted mean monthly reservoir inflow indicated an upward trend in all the three hydropower reservoirs. The scientific implication of the model results for the three hydropower stations in Nigeria revealed that there will be more inflow water into the hydropower reservoirs. All things being equal more power will be generated to the national grid which will boost power supply in the country provided the water is adequately harnessed. There is need for adequate reservoir operation to prevent the people at downstream from being flooded.

\section{CONCLUSION}

The ANN model results revealed that there was positive relationship between the actual and forecasted reservoir inflow with fairly high value of correlation coefficient for all the selected locations in the study area. This shows that the model is appropriate for the reservoir inflow modeling. The predicted reservoir inflow at Kainji, Jebba and Shiroro have upward trend, which indicate an increase inflow into the reservoirs in the near future. This will ensure more water for hydropower generation at the stations; however risk of flooding at stations is envisaged. Therefore, there is need for effective hydropower operation, planning and management in order to take adequate measures in tackling the envisaged challenges of flood.

\section{REFERENCES}

[1] Aslihan, A. Burak, B. and Bihrat, Ö. "Data Generation for Murat River with Artificial Neural Networks",
Water and Geoscience. 2010, ISSN: 1790-5095. pp. 73-77.

[2] de Vos, N. J. and Rientjes, T. H. M. "Multiobjective Training of Artificial Neural Networks for RainfallRunoff Modeling", Water Resour. Res., 2008, 44, W08434, doi:10.1029/2007WR006734.

[3] Tran, H. D. Muttil, N. and B. J. Perera, C. (2011) "Investigation of Artificial Neural Network Models for Streamflow Forecasting". 19 ${ }^{\text {th }}$ International Congress on Modelling and Simulation, Perth, Australia. pp. 1099-1105.

[4] Kang, B. and Ramerez, J. A. "Use of Artificial Neural Network for Regionalizing Numerical Weather Prediction and Global Climate Model", $8^{\text {th }}$ International Workshop on Precipitation in Urban Areas, St. Moritz, Switzerland, 2009, pp. 139 - 143.

[5] Hsu, K., Gupta, H. V. and Sorooshian, S. "Artificial Neural Network Modeling of the Rainfall - Runoff Process", Water Resources, Res., Vol. 31, Number10, 1995, pp. 2517-2530.

[6] Shamseldin, A. Y. "Application of a Neural Network Technique to Rainfall-Runoff Modeling", J. of Hydrol., 199, 1997, pp. 272-294.

[7] Zealand, C. M., Burn, D. H. and Simonovic, S. P. "Shortterm Streamflow Forecasting Using Artificial Neural Networks", J. of Hydrol., 214, 1999, pp. 32-48.

[8] Modarres, R. "Multi-Criteria Validation of Artificial Neural Network Rainfall-Runoff Modeling", Hydrol. Earth Syst. Sci. Discuss., 5, 2008, pp. 3449 - 3477.

[9] Karim, S. "Rainfall-Runoff Prediction Based on Artificial Neural Network: A Case Study: Jarahi Watershed", American-Eurasian J. Agric. \& Environ. Sci, Vol. 5 Number 6, 2009, pp. 856-865.

[10] Kevin, L. C. "Precipitation Prediction Using Artificial Neural Networks", M. Sc. Thesis Submitted to the Graduate Faculty of The University of Georgia, Republic of Georgia, 2008.

[11] Khaing, W. M. and Thinn, T. N. "Optimum Neural Network Architecture for Precipitation Prediction of Myanmar", World Academy of Science, Engineering and Technology, 48, 2008, pp. 130-134.

[12] Sunyoung, L., Sungzoon, C. and Patrick, M. W. "Rainfall Prediction Using Artificial Neural Networks", Journal of Geographic Information and Decision Analysis, Vol. 2, Number 2, (1998) pp. 233242.

[13] Hung, N. Q., Babel, M. S., Weesakul, S. and Tripathi, N. K. "An Artificial Neural Network Model for Rainfall Forecasting in Bangkok, Thailand", Hydrol. Earth Syst. Sci. Discuss., Vol. 5, pp. 2008, 183-218.

[14] Somvanshi, V. K., Pandey, O. P., Agrawal, P. K., Kalanker, N. V., Prakash, M. R. and Ramesh, C. "Modelling and Prediction of Rainfall Using Artificial Neural Network and ARIMA Techniques", J. Ind. 
Geophys. Union, Vol. 10, Number. 2, 2006, pp. 141151.

[15] Ricardo, M. T. and Jean, P. P. "Simulation of Daily Temperature for Climate Change Scenarios over Portugal: A Neural Network Model Approach", Climate Research, Vol. 13, 1999, pp. 45-59.

[16] Orosun, R. O. and Adamu, S. S. "Neural Network Based Model of an Industrial Oil-Fired Boiler". Nigerian Journal of Technology (NIJOTECH) Vol. 33, Number. 3, 2014, pp. 293-303.

[17] Adya, M. and Collopy, F. "How Effective are Neural Networks at Forecasting and Prediction? A Review and Evaluation", Journal of Forecasting, University of Maryland USA, 1998, pp. 481-482.

[18] Dibike, Y. B. and Solomatine, D. P. "River Flow ForecastingUsing Artificial Neural Networks". A Paper Presented at European Geophysical Society (EGS) XXIV General Assembly Hague, The Netherlands, and Accepted for publication in EGS Journal of Physics and Chemistry of the Earth. 1999, pp.1-8.

[19] Solaimani, K. "Rainfall-Runoff Prediction Based on Artificial Neural Network A Case Study: Jarahi Watershed Iran", American-Eurasian Journal Agriculture and Environmental Science, Vol. 5, Number 6, 2009, pp. 856-865.

[20] Kothyari, U. C. "Estimation of Mean Annual Flood from Ungauged Catchment using Artificial Neural Networks. Hydrology: Science and Practice for 21 $1^{\text {st }}$ Century". British Hydrological Society. Vol. 1, 2004, pp. 297-301.

[21] Diamantopoulou, M. J., Georgiou, P. E. and Papamichail, D. M. "Performance Evaluation of Artificial Neural Networks in Estimating Reference Evapotranspiration with Minimal Meteorological Data". Global NEST Journal Vol. 13, Number 1, 2011, pp. 18-27.
[22] Dastorania, M. T. and Afkhami, H. "Application of Artificial Neural Networks on Drought Prediction in Yazd (Central Iran)", DESERT, Vol.16, 2011, pp. 3948.

[23] Jeong, D. I. and Kim, Y. O. "Rainfall-Runoff Models using Artificial Neural Networks for Ensemble Streamflow Prediction", HYDROLOGICAL PROCESSES, Vol.19, 2005, pp. 3819-3835.

[24] Pulido-Calvo, I., Gutiérrez-Estrada J. C. and Savic, D. "Heuristic Modelling of the Water Resources Management in the Guadalquivir River Basin, Southern Spain", Water Resources Management. Vol. 26, 2012, pp. 185-209.

[25] Demirel, M. C. and Booij, M. J. "Identification of an Appropriate Low Flow Forecast Model for the Meuse River, Netherlands", (Proceeding of Symposium JS.4 at the Joint IAHS \& IAH Convention, Hyderabad, India 2009, pp. 296-300. http://www.doc.utwente.nl/78691/1/identificatio n_of.pdf. Assessed on April 24, 2012.

[26] Valent, P., Szolgay, J. and Riverso, C. “Assessment of the Uncertainties of a Conceptual Hydrologic Model by using Artificially Generated Flows". Slovak Journal of Civil Engineering, Vol. 20, Number 4, 2012, pp. $35-43$.

[27] Al Shamisi, M. H., Assi, A. H. and Hejase, H. A. N. "Using MATLAB to DevelopArtificial Neural Network Models for Predicting Global Solar Radiation in Al Ain City UAE". Engineering Education and Research, 2011, pp. 219-238.

[28] Chen, X. Wu, J. and $\mathrm{Hu}, \mathrm{Q}$. "Simulation of Climate Change Impacts on Streamflow in the Bosten Lake Basin using an Artificial Neural Network Model". Journal of Hydrologic Engineering. American Society of Civil Engineers, 2008, pp. 180-183. 